\title{
Lokalizacja zarządów i potencjał ekonomiczny wiodących firm zachodnio-europejskich
}

Współczesnym tendencjom rozwoju społeczno-gospodarczego towarzyszy nasilający się proces koncentracji kapitału w coraz większych i sprawniej działających korporacjach ponadnarodowych. W strukturze wiodących korporacji ponadnarodowych w miarę wzrostu kapitału nasila się integracja coraz bardziej zróżnicowanych elementów o funkcjach: zarządzających, produkcyjnych, badawczo-rozwojowych, usługowych, handlowych, finansowokapitałowych i logistycznych. Podstawowe znaczenia w procesie kształtowania tego typu firm mają ich zarządy, spełniające funkcje centrów decyzyjnych, które zarządzają tą złożoną, wielosektorową strukturą dynamiczną i wyznaczają poszczególnym elementom określoną pozycję na światowym rynku. W zależności od koniunktury gospodarczej centra decyzyjne uaktywniają zasoby kapitałowe, wpływając na zwiększenia rozmiarów dotychczasowej działalności, czy kreowanie nowych lokalizacji, celem wkraczania lub utrwalania swojej pozycji konkurencyjnej na związanych z nimi obszarach rynkowych. Podstawowym celem tej działalności jest dbałość o systematyczne podnoszenia konkurencyjności oferowanych produktów oraz osiaganie najkorzystniejszych wyników finansowych obecnie czy w najbliższym czasie.

Dzięki rozwojowi firm ponadnarodowych następuje nasilający się proces integracji europejskiej a także gospodarki światowej, który należy obecnie traktować jako obiektywny proces ekonomiczny związany z postępującym rozwojem cywilizacyjnym. Ten makroekonomiczny proces gospodarczy realizuje się odmiennie w konkretnych uwarunkowaniach złożonej przestrzeni geograficznej (Zioło 1996, 1999, 2001). Zróżnicowana przestrzeń geograficzna stwarza bowiem często odmienne warunki dla rozwoju i nasilania się procesów wzrostu społeczno-gospodarczego przejawiającej się w nasilaniu działalności ponadnarodowych firm, prowadzenia działalności produkcyjno-usługowej i kształtowania się ich obszarów rynkowych. W konsekwencji towarzyszy temu postępująca koncentracja przestrzenna poszczególnych elementów strukturalnych ponadnarodowych korporacji, w tym ich zarządów jako centrów decyzyjnych. Stąd wydaje się, iż na polu geografii przemysłu otwiera się nowe pole badawcze związane z koniecznością coraz precyzyjniejszego poznawania tych coraz bardziej złożonych procesów ekonomiczno-przestrzennych. Wydaje się, iż wypełnią one lukę zaznaczającą się między polem badań makroekonomicznych a polem badań geograficzno-ekonomicznych. Pozwolą one odpowiadać na pytanie, jakie jest odzwierciedlenie reguł rozwoju makroekonomicznego w różnej skali układów przestrzennych. Wydaje się, iż szczególne znaczenie ma tu poznanie prawidłowości przestrzen- 
nych związanych $\mathrm{z}$ podejmowaniem decyzji w zakresie kierunków rozwoju i penetracji ponadnarodowych firm dotyczących nowych lokalizacji oraz włączania przedsiębiorstw poszczególnych krajów w swoje struktury organizacyjne, zwłaszcza wobec nasilającej się coraz bardziej integracji europejskiej i postępujących procesów globalizacji.

W świetle przedstawionych przesłanek w niniejszych rozważaniach zmierzać będziemy do określenie rozmiarów potencjału produkcyjno-usługowego 1000 największych firm europejskich, zróżnicowania ich struktury branżowej oraz koncentracji przestrzennej ich zarządów (centrów decyzyjnych). Zakładamy bowiem, iż koncentracja przestrzenna centrów decyzyjnych jest wyrazem stopnia atrakcyjności przestrzeni europejskiej dla zarządzania działalnością produkcyjną, czy usługową tej kategorii firm europejskich.

Ogółem firmy te skupiają 2550,6 mld funtów kapitału akcyjnego, osiągnęły one łączny zysk przed opodatkowaniem 153,1 mld oraz zatrudniały 22,5 mln pracowników (tab. 1). Kapitał poszczególnych firm europejskich charakteryzował się dużym zróżnicowaniem i wahał się od 63,3 mld do 0,3 mld funtów a więc jak 212:1. W strukturze rangowej wiodących firm pierwsze pozycje zajmują dwa banki (European Inwestnen Bank, Societa Genaralne) których łączny kapitał akcyjny wynosi 117,2 mld funtów i stanowi 4,6\% ogólnej wartości analizowanych firm. Kolejne pozycje zajmują firmy branży paliwowej (Royal Dutch/Shell), energetycznej (Electrite de France) i finansowe (Cie de Suez). Te pięć największe firmy europejskie skupiają $9,6 \%$ kapitału i tylko 1,5\% pracujących. Wśród nich największym zyskiem odznacza się Royal Dutch/Shell, który wynosi 6,6 mld funtów.

Łącznie 20 największych firm europejskich charakteryzuje się dużą koncentracją kapitału i razem skupiają 22,7\% ogólnej wartości kapitału akcyjnego 1000 wiodących firm i $11,9 \%$ pracujących. Wśród nich dominujące znaczenie mają instytucje bankowofinansowe ( 7 firm), które obejmują blisko połowę tego kapitału (9,3\%) tej kategorii firm. Świadczy to o znaczącej pozycji tego sektora jako czynnika stymulującego proces wzrostu gospodarczego. Kolejną pozycję zajmują firmy paliwowe ( 5 firmy), skupiające $5,5 \%$ kapitału, a następnie samochodowe-transportowo-produkcyjne (4 firmy), energetyczne (2 firmy) i łączności (1 firma).

Wśród przemysłowych firm europejskich, pod względem kapitału, dominujące znaczenie mają: Royal Dutch/Shell (koncern brytyjsko-holenderski), który skupia 50,2 mld funtów kapitału (czyli 3,8\% wartości kapitału firm przemysłowych), Electricite de France $(3,4 \%)$, Daimler-Benz $(2,1 \%)$, Siemens $(1,9 \%)$, British Gas $(1,9 \%)$, Ste Elf Aquitaine $(1,7)$, Volkswagen, niemiecki koncern energetyczny RWE, British Petroleum Company oraz włoski koncern Fiata. Łącznie te dziesięć wiodących koncernów przemysłowych skupiają $21,2 \%$ kapitału firm przemysłowych.

Natomiast pod względem rozmiaru rynku pracy pierwszą pozycję zajmuje Siemens zatrudniający 393,9 tys. pracowników, tj. 2,9\% firm przemysłowych, Daimler-Benz (341,9 tys., 2,5\%), Unilever Group (Holandia, 30,4, 0 tys., 2,2\%), Fiat (256,6 tys., 1,9\%), Philips Electronics (249,7 tys.), Volkswagen (243,6 tys.), Nestle (212,7 tys.), BBC Brown Bover (Szwajcaria, inżynieria przemysłowa, 207,6 tys.), ABB Asea Brown (Szwajcaria, energetyka,

${ }^{1} \mathrm{O}$ przybliżonych rozmiarach kapitału tych banków może świadczyć fakt, iż w stosunku do PKB Polski, który w 1995 r. wynosił 127,1 mld dolarów USA, kapital European Investmen Bank wynosi $70,9 \%$ jego wartości, a w stosunku do kapitału Societa Generale $60,4 \%$. Łączny kapitał obu banków jest wyższy o $31,2 \%$ w stosunku do polskiego PKB (według kursu pierwszego tygodnia marca 2001. funta $1,4225 \mathrm{w}$ stosunku do $1 \mathrm{dol}$. USA). 


\begin{tabular}{|c|c|c|c|c|c|c|c|c|c|}
\hline \multirow{2}{*}{ Lokata } & \multirow{2}{*}{ Nazwa przedsiębiorstwa } & \multirow{2}{*}{ Państwo } & \multirow{2}{*}{ Sektor } & \multirow{2}{*}{ Siedziba } & \multirow{2}{*}{$\begin{array}{c}\text { Kapital } \\
\text { akcyjny w } \\
\text { mld funtow }\end{array}$} & \multirow{2}{*}{$\begin{array}{l}\text { Zysk przed } \\
\text { opodatkowa } \\
\text { niem mld } \\
\text { funtów }\end{array}$} & \multirow{2}{*}{$\begin{array}{l}\text { Zatrudnieni } \\
\text { e w tys. }\end{array}$} & \multicolumn{2}{|c|}{ Struktura } \\
\hline & & & & & & & & Kapitaku & $\begin{array}{l}\text { Zatrudnie } \\
\text { nia }\end{array}$ \\
\hline & European Investmen Bank & Luksemburg & Banki & Luksemburg & 63,3 & 0,9 & 0,8 & 2,5 & 0,00 \\
\hline & Societa Generale & Francja & Banki & Panyz & 53,9 & 0,7 & 44,4 & 2,1 & 0,20 \\
\hline & Royal Dutch/Shell & Holandia & Ropa, gas i paliwa jądrowe & Haga & 50,2 & 6,6 & 106,0 & 2,0 & 0,47 \\
\hline & Electricite de France & Francja & Energetyka & Paryz & 45,0 & 0,3 & 118,1 & 18 & 0,52 \\
\hline & Cie de Suez & Francja & Finanse & Paryz & 29,8 & 0,7 & 67,0 & 1,2 & 0,30 \\
\hline & Daimler-Benz & Niemcy & Transport-Produkcja i sprzedaz & Stuttgart & 27,5 & 0,8 & 341,9 & 1,1 & 1,52 \\
\hline & Siemens & Niemcy & Sprzęt elektryczny & Monachium & 25,4 & 0,8 & 393,9 & 1.0 & 1,75 \\
\hline & France Telecom & Francja & keacznosct & Paryz & 25,2 & 2,4 & 154,5 & 1,0 & 0,69 \\
\hline & Credit Lyonnais & Francja & Banki & Lyon & 24,6 & $-0,5$ & 71,4 & 1,0 & 0,32 \\
\hline 10 & British Gas & Wielka Brytania & Ropa, gas i paliwa jądrowe & Londyn & 24,6 & 0,9 & 70,0 & 1,0 & 0,31 \\
\hline 11 & SNCF & Francja & Ustugi transportowe & Paryz & 22,4 & $-1,0$ & 221,0 & 0,9 & 0,98 \\
\hline 12 & Ste Elf Aquitaine & Francja & Ropa, gas i paliwa jądrowe & Courbevoie & 22,3 & 0,4 & 94,3 & 0,9 & 0,42 \\
\hline 13 & Volkswagen & Niemcy & Transport-Produkcja i sprzedaz & Wolfsburg & 21,9 & 0,2 & 243,6 & 0.9 & 1,08 \\
\hline 14 & Deutsche Bank & Niemcy & Banki & Frankfurt & 21,8 & 1,2 & 65,1 & 0,9 & 0,29 \\
\hline 15 & RWE & Niemcy & Energetyka & Essen & 20,8 & 0,8 & 118,0 & 0,8 & 0,52 \\
\hline 16 & British Petroleum Company & Wielka Brytania & Ropa, gas i paliwa jądrowe & Londyn & 20,8 & 2,3 & 66,6 & 0,8 & 0,30 \\
\hline 17 & HSBC Hoidings & Wielka Brytania & Banki & Londyn & 20,6 & 3,2 & 106,9 & 0,8 & 0,47 \\
\hline 18 & Fiat & Whochy & Transport-Produkcja i sprzedaz & Turyn & 20,0 & $-0,6$ & 256,6 & 0,8 & $\overline{1,14}$ \\
\hline 19 & Union Bank of Switzerland & Szwajcaria & Banki & Zurich & 19,7 & 1,0 & 27,7 & 0,8 & 0,12 \\
\hline 20 & Veba & Niemcy & Ropa, gas i paliwa jądrowe & Dusseldorf & 19,5 & 1.2 & 126,9 & 0,8 & 0,56 \\
\hline & 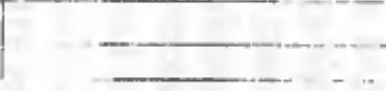 & Ogódem & $\frac{m}{500}$ firm & & $2 \frac{579,6}{550,6}$ & $\begin{array}{r}22,2 \\
153,1\end{array}$ & $\begin{array}{r}2 \frac{694,5}{22} \\
539,6 \\
\end{array}$ & $\begin{array}{r}22,7 \\
100,0\end{array}$ & $\begin{array}{r}11,95 \\
100,00 \\
\end{array}$ \\
\hline
\end{tabular}


207,6 tys.) Cie Generale des Eaux (zaopatrzenie w wodę, 204,3 tys.). Łącznie wymienione koncerny skupiają 2,6 mln pracujących, tj. 19,1\% zatrudnionych w firmach przemysłowych.

W strukturze 1000 największych firm europejskich zdecydowaną przewagę miały firmy skupiające ponad 10 mld funtów kapitału (tab. 2). W 54 firmach tej kategorii skupia się łącznie aż 41,2\% kapitału wiodących firm europejskich. Wyrównany udział pod względem udziału liczebności firm i kapitału miały firmy skupiające od 2 do 5 mld funtów, które obejmowały 181 firm i 22,3\% wartości kapitału. Natomiast pod względem liczebności zdecydowanie przeważały jednostki małe o wartości kapitału od 0,3 mld do 1,0 mld. Reprezentowało je 51,9\% firm, które skupiały tylko 11,3\% wartości kapitału.

Tabela 2. Koncentracja kapitału akcyjnego wiodących firm europejskich

\begin{tabular}{|c|c|c|c|c|c|}
\hline \multirow{2}{*}{ Lp. } & Wielkość kapitału akcyjnego & Liczba & Wartość kapitału akcyjne- & \multicolumn{2}{|c|}{ Struktura } \\
\cline { 5 - 6 } & w tys. funtów & go w tys. funtów & firm & kapitału \\
\hline 1 & $300-500$ & 256 & 102356928 & 25,6 & 4,0 \\
\hline 2 & $500-1000$ & 263 & 185292033 & 26,3 & 7,3 \\
\hline 3 & $1000-2000$ & 191 & 261426040 & 19,1 & 10,2 \\
\hline 4 & $2000-3000$ & 89 & 217483198 & 8,9 & 8,5 \\
\hline 5 & $3000-5000$ & 92 & 352273875 & 9,2 & 13,8 \\
\hline 6 & $5000-10000$ & 55 & 382180243 & 5,5 & 15,0 \\
\hline 7 & $10000-20000$ & 36 & 509192935 & 3,6 & 20,0 \\
\hline 8 & $20000-40000$ & 14 & 327927008 & 1,4 & 12,9 \\
\hline 9 & $40000-65000$ & 4 & 212463203 & 0,4 & 8,3 \\
\hline & Ogółem & 1000 & 2550595463 & 100,0 & 100,0 \\
\hline
\end{tabular}

Źródło: Por. tab. 1.

Podobnie największe firmy europejskie poważnym zróżnicowaniem charakteryzują się pod względem liczby pracowników, która waha się od 4 osób do 393,9 tys. osób. Dominujące znaczenie pod tym względem ma Firma Siemens zatrudniająca 393,9 tyś. pracowników, Daimler-Benz (341,9 tys.) a następnie Fiat (256,6 tys.), Volkwagen (243,6 tys.) i SNCF (221,0 tys.). Te pięć dominujących firm, stanowiących $0,5 \%$ ogólnej liczebności firm, skupia łącznie 6,5\% ogólnego zatrudnienia w 1000 największych firm europejskich. Znaczny stopień koncentracji zatrudnionych występuje w korporacjach skupiających ponad 50 tys. pracujących (tab. 3) ${ }^{2}$. Obejmują one 121 firm, czyli 12,1\%, a skupiają aż 54,2\% pracujących. W strukturze wielkościowej firm najliczniej występują korporacje mniejsze zatrudniające do 5 tys. pracujących. Łącznie obejmują one $28,2 \%$ firm, które skupiają tylko $2,4 \%$ pracujących.

Przedstawiona analiza wskazuje na bardzo duże zróżnicowanie potencjału produkcyjnego 1000 największych firm europejskich zarówno w świetle wartości kapitału akcyjnego jak i liczby pracujących. Stopień zróżnicowań wyrażają wskaźniki koncentracji kapitałowej i koncentracji pracujących. W świetle wartości wskaźników wyższą koncentracją analizowane firmy charakteryzują się pod względem wartości kapitału, czego wyrazem jest bardzo wysoki wskaźnik koncentracji kapitałowej wynoszący $0,453^{3}$ a nieco niższą koncentracją

\footnotetext{
${ }^{2}$ Analiza ta dotyczy 918 firm, które podały liczbę pracujących, pozostałe 82 firmy takich danych nie podało.

${ }^{3}$ Wskaźnik koncentracji kapitału $\left(W_{k}\right)$ w dominujących firmach obliczono według formuły:
} 
pracujących - wskaźnik koncentracji pracujących $-0,479^{4}$. Oznacza to, iż największe firmy europejskie wykazują stosunkowo duże zróżnicowanie pod względem badanych cech, przy czym bardziej różnicuje je wartość kapitału aniżeli liczba pracujących.

Tabela 3. Koncentracja pracujących w wiodących firmach europejskich

\begin{tabular}{|c|c|c|c|c|c|}
\hline \multirow{2}{*}{ Lp. } & \multirow{2}{*}{ Wielkość zatrudnienia w tys. } & \multirow{2}{*}{$\begin{array}{l}\text { Liczba } \\
\text { firm }\end{array}$} & \multirow{2}{*}{ Liczba pracujących } & \multicolumn{2}{|c|}{ Struktura } \\
\hline & & & & Firm & Pracujących \\
\hline 1 & $0-1$ & 73 & 25818 & 8,0 & 0,1 \\
\hline 2 & $1-5$ & 185 & 513116 & 20,2 & 2,3 \\
\hline 3 & $5-10$ & 179 & 1319406 & 19,5 & 5,9 \\
\hline 4 & $10-30$ & 278 & 4902618 & 30,3 & 21,8 \\
\hline 5 & $30-50$ & 92 & 3559379 & 10,0 & 15,8 \\
\hline 6 & $50-100$ & 66 & 4644188 & 7,2 & 20,6 \\
\hline 7 & $100-200$ & 32 & 4155050 & 3,5 & 18,4 \\
\hline 8 & $200-300$ & 9 & 2052991 & 1,0 & 9,1 \\
\hline 9 & $300-400$ & 4 & 1367031 & 0,4 & 6,1 \\
\hline & Ogółem & 918 & 22539597 & 100,0 & 100,0 \\
\hline
\end{tabular}

Źródło: Por. tab. 1.

Poziom zatrudnienia największych firm europejskich generalnie nawiązuje do wartości ich kapitału akcyjnego (tab. 4). Firmy o liczbie zatrudnionych do 30 tys. pracowników i do 2 mld kapitału obejmują łącznie $57,8 \%$ ich ogólnej liczby a firmy z przedziału od 2 mld funtów do 10 mld i od 30 tys. pracujących do 200 tys. obejmują $9,5 \%$ analizowanych firm. W poszczególnych przedziałach wielkościowych występują jednak duże zróżnicowania między wartościami analizowanych cech, np. największy pod względem kapitału European Investmen Bank o wartości 63,3 mld funtów zatrudnia tylko 0,8 tys. pracowników, co związane jest z faktem, iż jego działalność nastawiona jest głównie na usługi bardzo dużych europejskich kredytobiorców, podejmujących bardzo duże inwestycje. Duże zróżnicowanie liczby pracujących występuje także w przedziale wartości kapitałowej od 10 mld do 20 mld. Podobnie firmy zatrudniające od 100 tys. do 200 tys. pracowników odznaczają

$$
W_{k}=\frac{1}{200} \sum_{i=1}^{n}\left|p_{i}-k_{i}\right|
$$

gdzie: $p$-udział liczebności firm w i-tym przedziale,

$k$ - udział kapitału w firmach i-tego przedziału

$n$ - liczba przedzialów.

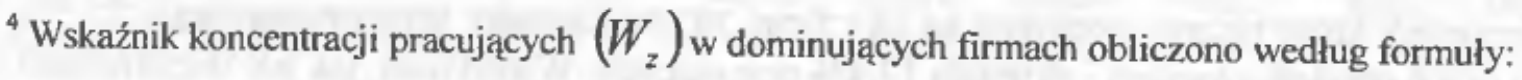

$$
W_{=}=\frac{1}{200} \sum_{i=1}^{n}\left|p_{i}-z_{i}\right|
$$

gdzie: $p$-udział liczebności firm w i-tym przedziale,

$z$ - udział pracujących w firmach i-tego przedziału

$n$ - liczba przedziałów. 
się bardzo dużym zróżnicowaniem wartości kapitału od ponad 0,3 mld funtów do ok. 50 mid. Relacje między liczbą pracujących a wartością kapitału w poszczególnych firmach podkreśla stosunkowo niska wartość współczynnika korelacji która wynosi 0,541. Zróżnicowania w tym zakresie bardzo silnie związane są z przynależnością branżową poszczególnych firm.

Tabela 4. Relacja miedzy wartością kapitału akcyjnego a liczbą pracujących w wiodących firmach europejskich

\begin{tabular}{|c|r|r|r|r|r|r|r|r|r|r|}
\hline $\begin{array}{c}\text { Wielkość } \\
\text { zatrudnie- } \\
\text { nia w tys. }\end{array}$ & \multirow{2}{*}{$\begin{array}{c}\text { Ogó- } \\
\text { lem }\end{array}$} & \multicolumn{8}{|c|}{ Wartość kapitału akcyjnego w mln. funtów } \\
\cline { 3 - 12 } & $0,3-0,5$ & $0,5-1,0$ & $1,0-2,0$ & $2,0-3,0$ & $3,0-5,0$ & $5,0-10,0$ & $\begin{array}{c}10,0- \\
20,0\end{array}$ & $\begin{array}{c}20,0- \\
40,0\end{array}$ & $\begin{array}{c}40,0- \\
65,0\end{array}$ \\
\hline $0-1$ & 73 & 28 & 28 & 9 & 5 & 0 & 1 & 1 & & 1 \\
\hline $1-5$ & 185 & 76 & 67 & 28 & 8 & 3 & 2 & 1 & & \\
\hline $5-10$ & 179 & 73 & 57 & 27 & 9 & 9 & 4 & & & \\
\hline $10-30$ & 278 & 45 & 77 & 63 & 38 & 34 & 15 & 6 & & \\
\hline $30-50$ & 92 & 4 & 11 & 32 & 19 & 14 & 9 & 2 & & 1 \\
\hline $50-100$ & 66 & 3 & 0 & 8 & 6 & 20 & 16 & 7 & 6 & \\
\hline $100-200$ & 32 & 2 & 0 & 2 & 2 & 4 & 5 & 12 & 3 & 2 \\
\hline $200-300$ & 9 & & & 1 & 0 & 0 & 1 & 4 & 3 & \\
\hline $300-400$ & 4 & & & & & & & 2 & 2 & \\
\hline $\begin{array}{c}\text { brak } \\
\text { danych }\end{array}$ & 82 & 25 & 23 & 21 & 2 & 8 & 2 & 1 & & \\
\hline Ogółem & 1000 & 256 & 263 & 191 & 89 & 92 & 55 & 36 & 14 & 4 \\
\hline
\end{tabular}

Źródło: Por. tab. 1.

Wiodące firmy europejskie charakteryzują się znacznym zróżnicowaniem struktury branżowej. Wśród 1000 największych firm europejskich, pod względem kapitału dominujące znaczenie mają banki, które występują najliczniej i reprezentuje je 103 jednostki, czyli $10,3 \%$ ich liczebności a skupiają aż 21,9\% kapitału (tab. 5). Znaczną koncentracją kapitału charakteryzują się także firmy reprezentujące sektor paliwowy $(8,9 \%$ kapitału), energetyczny $(8,2 \%)$, finanse $(5,2 \%)$ oraz transport - produkcję i sprzedaż $(5,1 \%)$. Wymienione sektory reprezentowane przez 292 firmy, charakteryzują się znaczną koncentracją kapitału i skupiają łącznie aż 49,3\% kapitału 1000 największych firm europejskich. Najmniejsze znaczenie mają mniej licznie firmy reprezentowane przez: sektor rolniczy ( 1 firma), instrumenty inżynierskie (4 firmy), przemysł włókienniczy (10 firm), przemysł tytoniowy (6 firm), które łącznie skupiają tylko $0,7 \%$ kapitału największych firm.

W strukturze sektorowej największych firm europejskich znaczącą rolę odgrywają instytucje finansowe (banki, finanse, instytucje ubezpieczeń, obsługa nieruchomości i fundusze powiernicze), które łącznie obejmują aż 281 firm, 34,0\% kapitału, wygospodarowały $28,5 \%$ zysku przed opodatkowaniem i skupiają 13,4\% pracujących. Wśród nich, jak już wspomniano dominuje 103 banków, które skupiają 21,9\% kapitału i tylko 7,2\% pracujących.

W strukturze firm europejskich działalność przemysłowa reprezentowana jest przez 538 koncerny, które łącznie skupiają $51,2 \%$ kapitału, wygospodarowały $55,3 \%$ zysku oraz obejmują $61,0 \%$ pracujących. Wśród nich największe znaczenie pod względem kapitału ma 
Tabela 5. Struktura sektorowa 1000 największych firm europejskich w $1996 \mathrm{r}$.

\begin{tabular}{|c|c|c|c|c|c|c|c|c|}
\hline \multirow[b]{2}{*}{ Lp } & \multirow[b]{2}{*}{ Sektor } & \multirow[b]{2}{*}{$\begin{array}{c}\text { Liczba } \\
\text { firm }\end{array}$} & \multicolumn{2}{|c|}{ w mid funtow } & \multirow[b]{2}{*}{$\begin{array}{c}\text { Zatrudnieni } \\
\text { ew tys. }\end{array}$} & \multicolumn{3}{|c|}{ Struktura } \\
\hline & & & $\begin{array}{l}\text { Kapitał } \\
\text { akcyjny }\end{array}$ & \begin{tabular}{|c|}
$\begin{array}{c}\text { Zysk przed } \\
\text { opodatkow } \\
\text { aniem }\end{array}$ \\
\end{tabular} & & $\begin{array}{l}\text { Kapital } \\
\text { akcyiny }\end{array}$ & $\begin{array}{c}\begin{array}{c}\text { Zysk przed } \\
\text { opodatkow } \\
\text { aniem }\end{array} \\
\end{array}$ & $\begin{array}{c}\text { Zatrudnie } \\
\text { nie }\end{array}$ \\
\hline 1 & Banki & 103 & 557,3 & 28.9 & 1606,4 & 21,9 & 18,9 & 7.1 \\
\hline 2 & Ropa, gas i paliwa jądrowe & 39 & 226,6 & 17,7 & 854,0 & 8,9 & 11,6 & 3.8 \\
\hline 3 & Energetyka & 60 & 208,4 & 11,7 & 807,6 & 8,2 & 7.7 & 3,6 \\
\hline 4 & Finanse & 61 & 133,0 & 3,1 & 693,8 & 5,2 & 2,0 & 3,1 \\
\hline 5 & Transport-Produkcja i sprzeday & 29 & 130,3 & 2,8 & 1696,4 & 5,1 & 1,8 & 7,5 \\
\hline 6 & Ubezpieczenia & 46 & 109,9 & 9,5 & 623,5 & 4,3 & 6,2 & 2,8 \\
\hline 7 & Usługi transportowe & 48 & 109,3 & $-0,7$ & 1238,8 & 4,3 & $-0,5$ & 5,5 \\
\hline 8 & Przemysl chemiczny & 33 & 106,4 & 6,8 & 1125,5 & 4,2 & 4,4 & 5,0 \\
\hline 9 & Inżynieria przemysłowa & 64 & 83,0 & 2,5 & 1649,2 & 3,3 & 1,7 & 7,3 \\
\hline 10 & Hutnictwo i metalurgia & 34 & 75,0 & 1,7 & 830,0 & 2.9 & 1,1 & 3,7 \\
\hline 11 & Zywnosc & 33 & 65,6 & 9,5 & 1062,6 & 2,6 & 6,2 & 4,7 \\
\hline 12 & kącznosc & 4 & 61,9 & 6.9 & 541,1 & 2,4 & 4,5 & 2,4 \\
\hline 13 & Kosmetyki & 35 & 61,4 & 9,7 & 808,3 & 2,4 & 6,3 & 3,6 \\
\hline 14 & Sklepy & 40 & 47,8 & 5,0 & 1291,8 & 1,9 & 3,2 & 5,7 \\
\hline 15 & Elektronika & 20 & 42,6 & 2,0 & 743,2 & 1,7 & $1,3^{t}$ & 3,3 \\
\hline 16 & Browary & 23 & 42,5 & 4,6 & 405,9 & 1,7 & 3,0 & 1,8 \\
\hline 17 & Sprzęt elektryczny & 8 & 40,5 & 1,8 & 721,1 & 1,6 & 1,1 & 3,2 \\
\hline 18 & Materiahy budowlane & 36 & 39,0 & 3,2 & 471,3 & 1,5 & 2.1 & 2,1 \\
\hline 19 & Nieruchomosci & 36 & 37,5 & 1,2 & 61,0 & 1,5 & 0,8 & 0,3 \\
\hline 20 & Telekomunikacja & 13! & 36,1 & 2,7 & 524,1 & 1,4 & 1,8 & 2,3 \\
\hline 21 & Biura konstrukcyjne & 33 & 35,5 & 1,7 & 779,7 & 1,4 & 1,1 & 3,5 \\
\hline 22 & Mieszany & 22 & 32,9 & 1,7 & 508,4 & 1,3 & 1,1 & 2,3 \\
\hline 23 & Zaopatrzenie w wode & 13 & 30,5 & 2,0 & 276,8 & 1,2 & 1,3 & 1,2 \\
\hline 24 & Inny przemyst materialowy & 16 & 29,1 & 1,1 & 499,6 & 1,1 & 0,7 & 2,2 \\
\hline 25 & Media & 25 & 28,9 & 4,0 & 285,0 & 1,1 & 2,6 & 1,3 \\
\hline 26 & Fundusze powiernicze & 35 & 28,5 & 0,8 & 35,8 & 1,1 & 0,5 & 0,2 \\
\hline 27 & Opakowania papierowe & 26 & 27.0 & 0,9 & 244,9 & 1.1. & 0,6 & 1,1 \\
\hline 28 & Kopalnie & 7. & 25,2 & 1,3 & 190,4 & 1,0 & 0,9 & 0,8 \\
\hline 29 & Sprzedaz zywnosci & 16 & 21,5 & 1,8 & 651,4 & 0,8 & 1.2 & 2.9 \\
\hline 30 & Konglomeraty & 3 & 21,4 & 2,9 & 298,6 & 0,8 & 1.9 & 1,3 \\
\hline 31 & Hotele & 9 & 18,1 & 0.5 & 353,0 & 0,7 & 0,3 & 1,6 \\
\hline 32 & Lotniczy przemyst & 9 & 14,3 & 0,0 & 221,4 & 0,6 & 0,0 & 1,0 \\
\hline 33 & Tyton & 6 & 13,5 & 2,9 & 131,1 & 0,5 & 1,9 & 0,6 \\
\hline 34 & Wiokiennictwo & 10. & 6,0 & 0,5 & 165,9 & 0,2 & 0,3 & 0,7 \\
\hline 35 & Instrumenty Inzynieryjne & 4 & 3,7 & 0,4 & 68,8 & 0,1 & 0,2 & 0,3 \\
\hline \multirow[t]{2}{*}{36} & Rolnictwo & 1 & 0,3 & 0,0 & 73,3 & 0,0 & 0,0 & 0,3 \\
\hline & Ogolem & 1000 & 2550,6 & 153,1 & 22539,6 & 100,0 & $100,0 !$ & 100,0 \\
\hline
\end{tabular}

Źródło: Por. tab. 1.

39 koncernów reprezentujących przemysł ropy naftowej, gazu i paliw jądrowych, które łącznie skupiają $8,9 \%$ kapitału, $11,6 \%$ zysków i 3,4\% pracujących. Drugą pozycję zajmuje 60 koncernów energetycznych, które obejmują 8,2\% kapitału, 7,7\% zysków i 3,6\% pracujących a trzecia pozycja przypada na 29 koncernów sektora produkcji i sprzedaży samochodów, które 
obejmują 5,1\% kapitału i 7,5\% pracujących. Te trzy dominujące sektory przemysłowe reprezentowane przez 128 koncernów skupia łącznie 22,2,\% kapitału, i 14,9\% zatrudnionych.

Kolejne pozycje zajmują koncerny przemysłu: chemicznego (33 firm), inżynierii przemysłowej (64 firm), hutnictwa i metalurgii (34) i przemysłu kosmetycznego (35). Lącznie obejmują one 166 firm oraz 12,8\% kapitału i 19,6\% pracujących. Dalsze miejsca zajmują: firmy elektroniczne (20), browary (23), producenci sprzętu elektrycznego (8), materiałów budowlanych (36), biura konstrukcyjne (33) i zaopatrzenia w wodę (13), które łącznie skupiają $9,1 \%$ kapitału dominujących firm oraz $15,1 \%$ pracowników.

Generalnie należy stwierdzić, iż w strukturze 1000 największych firm europejskich podstawową rolę odgrywają korporacje przemysłowe obejmujące $52.5 \%$ ich ogólnej liczby a następnie instytucje bankowo-finansowe $(28,1 \%)$, komunikacyjne $(9,0 \%)$, handlowe $(5,6 \%)$ i pozostałe sektory gospodarki $(4,8 \%)$.

W wyniku historycznego procesu wzrostu gospodarczego poszczególne kraje zachodnie na swoim terenie stwarzały różne możliwości rozwoju centrów decyzyjnych (zarządów) wiodących firm europejskich. Wpływa na to w głównym stopniu potencjał gospodarczy danego kraju kształtujący się w fazie industrialnego rozwoju, rozwój myśli technicznej i systematyczne wdrażanie metod innowacyjnego zarządzania nawiązującego do rozwoju organizacyjno-technicznego. Dlatego najwięcej siedzib zarządów wiodących firm europejskich skupia się na terenie Wielkiej Brytanii, bo aż 332, czyli 33,2\% ich liczebności (tab. 6).

Tabela 6. Struktura przestrzenna 1000 największych firm europejskich w $1996 \mathrm{r}$.

\begin{tabular}{|c|c|c|c|c|c|c|c|}
\hline \multirow[b]{2}{*}{ Lp. } & \multirow[b]{2}{*}{ Kraje } & \multirow[b]{2}{*}{$\begin{array}{l}\text { Liczba } \\
\text { firm }\end{array}$} & \multicolumn{2}{|c|}{ w mld funtów } & \multirow[b]{2}{*}{$\begin{array}{l}\text { Zatrudnie- } \\
\text { nie w tys. }\end{array}$} & \multicolumn{2}{|c|}{ Struktura } \\
\hline & & & $\begin{array}{l}\text { Kapital } \\
\text { akcyjny }\end{array}$ & $\begin{array}{c}\text { Zysk przed } \\
\text { opodatkowaniem }\end{array}$ & & $\begin{array}{c}\text { Kapital } \\
\text { akcyjny }\end{array}$ & $\begin{array}{l}\text { Zatrudnie- } \\
\text { nie }\end{array}$ \\
\hline 1 & Wielka Brytania & 332 & 599,8 & 64,9 & 5989,1 & 23,5 & 26,6 \\
\hline 2 & Francja & 131 & 551,5 & 15,7 & 4484,3 & 21,6 & 19,9 \\
\hline 3 & Niemcy & 134 & 428,3 & 30,4 & 4855,8 & 16,8 & 21,5 \\
\hline 4 & Szwajcaria & 70 & 183,6 & 16,4 & 1495,9 & 7,2 & 6,6 \\
\hline 5 & Holandia & 45 & 176,0 & 17,7 & 1479,7 & 6,9 & 6,6 \\
\hline 6 & Włochy & 59 & 149,7 & $-3,3$ & 1264,0 & 5,9 & 5,6 \\
\hline 7 & Hiszpania & 39 & 113,1 & 2,4 & 587,7 & 4,4 & 2,6 \\
\hline 8 & Szwecja & 52 & 79,3 & 8,1 & 868,9 & 3,1 & 3,9 \\
\hline 9 & Luksemburg & 7 & 73,4 & 1,5 & 47,7 & 2,9 & 0,2 \\
\hline 10 & Belgia & 32 & 67,4 & 2,9 & 426,7 & 2,6 & 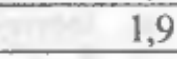 \\
\hline 11 & Finlandia & 27 & 34,5 & 1,4 & 297,2 & 1,4 & 1,3 \\
\hline 12 & Dania & 19 & 25,0 & 1,3 & 335,5 & 1,0 & 1,5 \\
\hline 13 & Norwegia & 18 & 24,4 & 2,7 & 139,2 & 1,0 & 0,6 \\
\hline 14 & Austria & 19 & 23,6 & $-0,5$ & 156,6 & 0,9 & 0,7 \\
\hline 15 & Portugalia & 7 & 12,6 & 0,3 & 43,7 & 0,5 & 0,2 \\
\hline 16 & Irlandia & 6 & 5,7 & 0,8 & 54,1 & 0,2 & 0,2 \\
\hline 17 & Lichtenstein & 3 & 2,6 & 0,2 & 13,4 & 0,1 & 0,1 \\
\hline & Ogólem & 1000 & 2550,6 & 153,1 & 22539,6 & 100,0 & 100,0 \\
\hline
\end{tabular}

Źródło: Por. tab. 1.

Obejmują one $23,5 \%$ kapitału i $25,6 \%$ pracujących. Kolejną pozycję zajmuje Francja (131 siedziby firm, 21,6\% kapitału) i Niemcy (134 firm i 16,8\% kapitału) Te trzy kraje odgry- 
wają więc dominującą rolę $\mathrm{w}$ tym zakresie a na ich terenie skupia się łącznie 597 siedzib firm, czyli 59,7\%, zarządzających $61,9 \%$ wartości kapitału i skupiających w swoich korporacjach $68,0 \%$ pracujących. W wyniku tak dużej koncentracji centrów decyzyjnych wiodących firm oraz związanego z nimi potencjału produkcyjnego i kapitału, kraje te odgrywają wiodącą rolę w strukturach Unii Europejskiej, tworząc podstawowy trzon ekonomiczny tej nowo kształtującej się struktury gospodarczej.

Mniejszą rolę pod tym względem odgrywa: Szwajcaria (70 firm), Holandia (45), Włochy (59), Hiszpania (39), Szwecja (52). Lącznie obejmują one 265 firm, których łączny kapitał wynosi $27,5 \%$ i skupiają $25,3 \%$ pracujących. Znacznie mniejsze znaczenia mają pozostałe 9 krajów europejskich (Luksemburg, Belgia, Finlandia, Dania, Norwegia, Austria, Portugalia, Irlandia, Lichtenstein), na terenie których skupia się 13,8\% firm, które obejmują tylko $10,6 \%$ kapitału i $6,7 \%$ pracujących.

Na terenie poszczególnych krajów występują centra decyzyjne firm reprezentujące różne sektory gospodarcze. Wszystkie rodzaje firm mają swoje siedziby na terenie Wielkiej Brytanii a w miarę zmniejszania się ich liczby na terenie pozostałych krajów, występują one coraz bardziej sporadycznie. Centra decyzyjne sektora przemysłowego, występują powszechnie bądź sporadycznie. Duża koncentracja siedzib zarządów firm reprezentujących przez wszystkie branże występuje na terenie Wielkiej Brytanii (145 zarządów), Niemiec (101), Francji (69). a następnie już sporadycznie występują reprezentacje wybranych branż na obszarze Szwecji (38), Szwecji (33), Włoch, Holandii i Hiszpanii.

Na terenie poszczególnych krajów możemy dostrzec dominację firm reprezentujących różne branże (tab. 7). Na terenie Wielkiej Brytanii najliczniej występują siedziby zarządów reprezentujących ropę, gaz i paliwa jądrowe, (gdzie z ogółu 39 zarządów firm, na terenie tego kraju występuje 15 zarządów), a następnie materiały budowlane, przemysł chemiczny, elektronikę i browary. Na terenie Niemiec najliczniej występują zarządy firm reprezentujących inżynierię przemysłową (19) i sprzęt elektryczny. Na terenie tych obu krajów w zbliżonej liczbie występują firmy reprezentujące energetykę (z ogółu tego typu zarządów 60, na terenie Wielkiej Brytanii występuje 20 zarządów a na terenie Niemiec 17). Na terenie Wielkiej Brytanii i Francji skupiają się zarządy firm żywnościowych a na terenie trzech wspomnianych krajów zarządy firm transportu i produkcji i sprzedaży. Biura konstrukcyjne, które należy uznać za ośrodki innowacyjne, bazujące na nauce i służące bezpośrednio produkcji występują najliczniej na terenie Francji (7), Niemiec (6) Wielkiej Brytanii (5) oraz w Hiszpanii i Szwecji (po 4). Uwarunkowania krajowe sprawiają, iż na terenie Wielkiej Brytanii i Finlandii skupiają się siedziby firm opakowań papierowych.

Stosunkowo silną koncentrację wykazują zarządy firm bankowo-finansowych. Z ogółu 281 ich liczby, na terenie Wielkiej Brytanii występuje ich 108, a na terenie Francji (32), Włoch (24), Szwajcarii (23), i Niemiec (16).

Podobnie większość zarządów, reprezentujących firmy komunikacyjne (z ogółu 90), występuje na terenie Wielkiej Brytanii (31) i Francji (12), Holandii (7) i Niemiec (6). Większość zarządów reprezentujących pozostałe sektory gospodarki występuje na terenie Wielkiej Brytanii. Podobnie wiodąca rola tego kraju zaznacza się w zakresie siedzib zarządów firm handlowych i pozostałych. 


\section{D.}

\begin{tabular}{|c|c|c|c|c|c|c|c|c|c|c|c|c|c|c|c|c|c|c|}
\hline & & & & & & & & & Pan & stwa & & & & & & & & \\
\hline Sektor & $\begin{array}{l}\underline{E} \\
\text { 点 } \\
\text { 莡 } \\
\underline{\underline{J}}\end{array}$ & 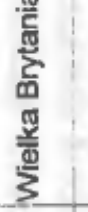 & 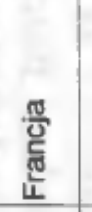 & $\begin{array}{l}\text { ठे } \\
\text { हू } \\
\text { ¿ }\end{array}$ & 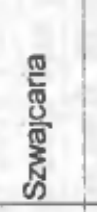 & $\begin{array}{l}\text { 묘 } \\
\text { 듬 } \\
\text { 임 }\end{array}$ & $\begin{array}{l}\vec{c} \\
\frac{0}{0} \\
\frac{0}{3}\end{array}$ & 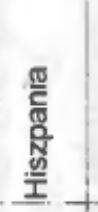 & 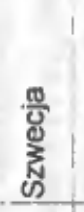 & 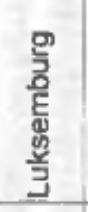 & $\begin{array}{l}\frac{m}{0} \\
\frac{5}{\Phi} \\
.0\end{array}$ & 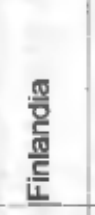 & 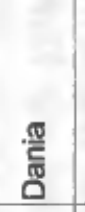 & $\begin{array}{l}\text { 爱 } \\
\text { 己. } \\
\text { 己 }\end{array}$ & $\begin{array}{l}\frac{0}{5} \\
\frac{5}{3} \\
\frac{3}{2}\end{array}$ & 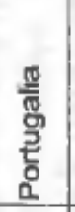 & 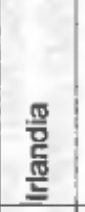 & 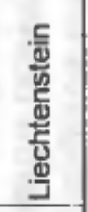 \\
\hline I. Razem przemyst, w tym: & 525 & 145 & 69 & 101 & 38 & $\underline{21}$ & 26 & 20 & 33 & 2 & 15 & 19 & 7 & 10 & 13 & 3 & 2 & 1 \\
\hline Inzynieria przemystowa & 64 & 12 & 2 & 19 & 9 & $\underline{2}$ & 4 & 1 & 6 & & & 4 & 2 & 1 & 1 & & & 1. \\
\hline Energetyka & $6 \overline{0}$ & 20 & 1 & $\overline{17}$ & 4 & 1 & & 7. & 4 & & 2 & & & T & 3 & 1. & & \\
\hline Ropa, gas i paliwa jadrowe & 39 & 15 & 6 & 5 & & 2 & 2 & 3 & 1 & & 1 & 1 & & 2 & 1 & & 7 & \\
\hline Materiały budowiane & 36 & 12 & 5 & 2 & 5 & 1 & 3 & 2 & 1 & & 1 & 1 & 7 & 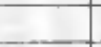 & 2 & & 1 & \\
\hline Kosmetyki & 35 & 8 & 4 & 9 & 4 & 1 & & & 4 & & + & 1 & 2 & 2 & & & & \\
\hline Hutnictwo i metalurgia & 34 & 2 & 4. & $\underline{B}$ & 1. & 1 & 3 & 1 & 5 & 1 & 4 & 2 & & 1 & 1 & & & \\
\hline Przemysi chemiczny & 33 & 9. & 3 & $\overline{6}$ & 2 & 2 & 3 & & 2 & & 3 & 1 & & 2 & & & & \\
\hline Zywnose & 33 & 11 & 8 & 1 & 3 & 5 & 1 & 1 & & & 7 & 2 & & 1 & & & 1 & \\
\hline Biura konstrukcyjne & $3 \overline{3}$ & 5 & 7 & 6 & & 1 & 2 & $\overrightarrow{4}$ & 4 & & 1 & 1 & & 1 & 1 & & & \\
\hline Transport-Produkcja i sprzedaz & 291 & 8 & 6 & 10 & & & 1 & & 2 & & 1 & & & T & 1 & & & \\
\hline Opakowania papierowe & 26 & 5 & 2 & 3 & 3 & 1. & 2 & & 2 & & & 4 & & 1 & 1 & 2 & & \\
\hline Browary & 23 & 12 & 4 & 2. & 2. & 1. & & & & & & & 1 & & 1 & & & \\
\hline Elektronika & 20 & 8 & 4 & 3 & & 2. & 2 & & ++ & & & 1 & & & 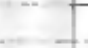 & & & \\
\hline inny przemysi materialowy & 16 & 5 & 3 & 3 & 1 & + & 1 & & 1 & & 1 & 1 & + & & 7 & & & \\
\hline Włókiennictwo & 10 & 4. & 3 & & & & 2 & & & & +1 & & & & 1 & & & \\
\hline Lotniczy przemysi & $\overline{9}$ & 3 & 3 & & 1. & 1 & & & & & 1 & & & & & & & \\
\hline Sprzęt elektryczny & 8 & 1 & 2 & 3 & & & & & 1 & & & & 1. & & & & & \\
\hline Kopalnie & 7. & 2 & 1 & 2 & 1. & & & & & 1 & & & & & 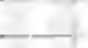 & & & \\
\hline Tyton & 6 & 2. & 1 & 1. & 1 & & & 1 & & & & & & & - & & & \\
\hline Instrumenty inzynieryjne & 4 & 1 & & 1. & 1. & & & & & & & & 1. & & 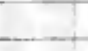 & & & \\
\hline $\begin{array}{l}\text { II. Razem instytucje finansowe, w } \\
\text { tym: }\end{array}$ & 281 & 108 & 32 & 16 & 23 & 14 & 24 & 13 & 7 & 5 & 14 & 4 & 6 & 2 & 4 & 4 & 3 & 2 \\
\hline Banki & 103. & 21 & $\underline{9}$ & 9 & 11 & 2 & 11 & 9 & 2 & 4 & 4 & 3 & 4 & 2 & 4 & 4 & 2 & 2 \\
\hline Finanse & 61 & 26 & 8 & 1 & 6 & 4 & 6 & 1 & 2. & 1 & 5 & & & & & & 1 & \\
\hline Ubezpieczenia & $4 \overline{6}$ & 12 & 6 & 6 & 5 & 4 & 6 & 1 & 2 & & 1 & 1 & 2 & & & & & \\
\hline Nieruchomasci & 36 & 20 & 8 & & $\overline{1}$ & 2 & 1. & 2 & 1 & & 1 & & & & & & & \\
\hline Fundusze powiernicze & 35 & 29 & 1 & & & 2 & & & & & 3 & & & & & & & \\
\hline
\end{tabular}


Bx

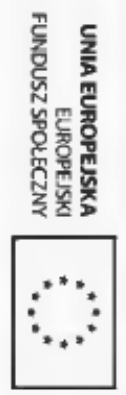

\begin{tabular}{|c|c|c|c|c|c|c|c|c|c|c|c|c|c|c|c|c|c|}
\hline III. Razem komunikacja, w tym: & 90 & 31 & 12 & 6. & 4 & 7 & 4 & 4 & 8 & & 1 & 2 & 2 & 6 & 2 & & 1 \\
\hline Ustugi transportowe & 48. & 12 & 5 & 3 & 2 & 5 & 1 & 3 & 5 & & 9 & 2 & $\overline{1}$ & $\overline{6}$ & 2 & & \\
\hline Media & 25 & 12 & 5 & 2 & 1 & 2 & 1 & & 1 & & & & & & & & 1 \\
\hline Telekomunikacja & 13 & 5 & & 1 & 1 & & 2 & 1. & 2 & & & & 1 & & & & \\
\hline tacznosć & 4 & 2 & 2) & & & & & & 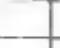 & & & & + & & & & \\
\hline IV. Razem handel, w tym: & 56 & 24 & 9 . & 7. & 4 & 2 & 2 & & 3 & & 2 & 1 & 2 & & & & \\
\hline Sklepy & 40 & 16 & 7 & 7 & 2 & 1 & 2 & & 3 & & 1 & & 1 & & & & \\
\hline Sprzedaz zywnosci & 16 & 8 & 2 & & 2 & 1 & & & 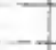 & & 1 & 1 & 1 & & & & \\
\hline V. Razem pozostale, w tym: & 48 & 24 & 9 & 4 & 1 & 1 & 3 & 2. & 1. & & & 1 & 2. & & & & \\
\hline Mieszany & 22 & 3 & 5 & 4 & 1 & 1. & 3. & 1 & 1 & & & 1 & 2 & & & & \\
\hline Zaopatrzenie w wode & 13 & 11 & 1 & & & & & 1 & & & & & & & & & \\
\hline Hotele & 9 & 6 & 3 & & & & & & & & & & & & & & \\
\hline Konglomeraty & 3. & 3 & & & & & & & & & & & & & & & \\
\hline Rolnictwo & 1 & 1 & & & & & & & & & & & & & & & \\
\hline Ogółem & 1000 & 332 & 131 & 134 & 70 & 45 & 59 & 39 & 52 & 7 & 32 & 27 . & 19 & 18 & 19 & 7 & 6 \\
\hline
\end{tabular}


Przedstawiona analiza potwierdza, iż przestrzeń gospodarcza poszczególnych państw Europy Zachodniej jest bardzo zróżnicowana i stwarza często odmienne warunki dla koncentracji centrów decyzyjnych wiodących firm europejskich zarządzających kapitałami i wpływającymi na ich strategie rozwoju. Najkorzystniejsze warunki w tym zakresie występują na terenie trzech dominujących państw Unii Europejskiej (Wielka Brytania, Francja, Niemcy), które łącznie skupiają $59,7 \%$ centrów decyzyjnych wiodących firm i spełniają funkcję podstawowych segmentów złożonej gospodarki tej organizacji. Pozostałe obszary rozwijają się przeważnie w oparciu o reguły powiązań komplementarnych.

Na tym tle należy wnosić, iż obecnie kraje Europy Środkowej, w tym Polska, reprezentują znacznie mniej korzystne warunki dla lokalizacji centrów decyzyjnych tego typu firm, czyli pod tym względem są obszarami mniej konkurencyjnymi. Dlatego obecnie szczególnie ważnym dla nich problemem jest podniesienie konkurencyjności ich przestrzeni gospodarczej oraz przyciąganie na swój teren w pierwszym etapie znaczących oddziałów produkcyjnych firm europejskich i światowych, które wykształcą powiązania produkcyjne z miejscowymi przedsiębiorstwami a później wpłyną na lokalizację na ich terenie zarządów koncernów ponadnarodowych oraz ich otoczenia biznesowego i naukowo-badawczego.

\section{Literatura}

Zioło Z., 1996, Problematyka ksztaltowania nowej przestrzeni przemystowej [w:] Polska w Europie Battyckiej (red. E. Rydz). 45. Zjazd Polskiego Towarzystwa Geograficznego, PTG Oddz. w Słupsku, Instytut geografii WSP w Słupsku. Słupsk-Ustka s. 300-303.

Zioło Z., 1999, Model funkcjonowania przestrzeni geograficznej jako próba integracji badań geograficznych [w:] Geografia na przelomie wieków - jedność w różnorodności (red. A. Lisowski). Wydział Geografii i Studiów Regionalnych Uniwersytetu Warszawskiego, Warszawa 1999, s. 122-131.

Zioło Z., 2001, Struktura branżowa $i$ koncentracja przestrzenna wiodacych światowych firm przemystowych [w:] Problemy przemian struktur przemyslowych $w$ procesie wdrażania regut gospodarki rynkowej (red. Z. Zioło) Prace Komisji Geografii Przemysłu Polskiego Towarzystwa Geograficznego, nr 3, Warszawa-Kraków-Rzeszów 2001, s. 29-41. 